\title{
Strategi Promosi Sarung Tenun Samarinda Sebagai Produk Wisata Budaya di Samarinda
}

\author{
Novita Indriani ${ }^{1}$, Musdalifah ${ }^{2}$, Rini Koen Iswandari ${ }^{3}$, Indah Puspasari ${ }^{4}$ \\ I.novitaIndriani@polnes.ac.id.2.musda14@polnes.ac.id.3.rini02@polnes.ac.id; \\ ${ }^{a}$ Jurusan Pariwisata Politeknik Negeri Samarinda, Alamat, Kota Samarinda 75131, Indonesia \\ 1,2 Jl. DR. Ciptomangunkusumo, Kampus Gunung Lipan, Samarinda, Kalimantan Timur, Indonesia 75131 \\ | Hot line: PABX (+62541) 260588, FAX: (+62541) 260355
}

\begin{abstract}
ARTICLE INFO
ABSTRACT

Article history:

Received 12 Feb 2019

Revised 15 April 2019

Accepted 1 Juni 2019

Mengajukan ISSN

Keywords:

Strategi promosi, produk wisata

Penelitian ini bertujuan untuk mengetahui strategi promosi yang dilakukan oleh pihak pengrajin maupun Dinas Pariwisata dalam melakukan promosi terhadap Sarung Tenun Samarinda Sebagai Produk Wisata Budaya di Samarinda. Berdasarkan hasil penelitian menunjukkan bahwa promosi yang dilakukan oleh pengrajin belum dilakukan secara maksimal, selain itu Dinas Pariwisata sebagai pengambil kebijakan belum maksimal terlibat dalam melakukan upaya promosi. Metode observasi, wawancara dan studi pustaka digunakan sebagai cara pengumpulan data setelah itu dianalisis menggunakan analisis deskriptif kualitatif. Pendekatan SWOT digunakan untuk menganalisi faktor internal dan eksternal kondisi saat ini di Sarung Tenun Samarinda.
\end{abstract}

Copyright (C) 2019 Politeknik Negeri Samarinda.

All rights reserved.

\section{Latar belakang}

Indonesia merupakan negara kepulauan yang memiliki potensi pariwisata yang tersebar diseluruh pelosok nusantara dimana masing-masing daerah mempunyai daya tarik wisata yang berbeda-beda. Pariwisata adalah suatu industri yang bisa menghasilkan banyak devisa bagi suatu negara. Pariwisata merupakan industri tanpa asap yang menyerap banyak tenaga kerja. Karena bagaimanpun majunya pariwisata tidak akan meninggalkan sumber daya manusia sebagai pelaku utama yang tidak bisa digantikan oleh mesin-mesin. Secara umum pariwisata dipandang sebagai sektor yang dapat mendorong dan meningkatkan kegiatan pembangunan, membuka lapangan usaha baru, membuka lapangan kerja, dan dapat meningkatkan pendapatan masyarakat serta pendapatan asli daerah, apabila dikelola dan dikembangkan secara maksimal. Pariwisata Indonesia sejak dulu lebih mengutamakan pada pariwisata berbasis budaya dan alam, dalam hal ini dapat diketahui bahwa budaya juga tidak terlepas dari sejarah yang mendominasi kegiatan budaya tersebut,karena budaya sendiri merupakan hasil-hasil seni budaya masyarakat setempat seperti adat istiadat,upacara agama, maupun kerajinana-kerajinan rakyat, dan hasilhasil budaya sendiripun perlu dilestarikan dan dijaga keberadaanya oleh semua masyarakat. 
Kerajinan rakyat pun dapat menjadi salah satu objek wisata yang unik bagi banyak orang yang memiliki minat pada wisata budaya, beberapa kerajinan rakyat yang unik adalah kerajinan tenun sarung yang banyak terdapat dibeberapa daerah,tidak hanya keunikan dari motif atau corak yang terdapat pada sarung tetapi juga nilai-nilai sejarah serta budaya yang terkandung didalamya serta kerajinan yang dibuat memang asli karya masyarakat setempat. kain sarung telah lama dikenal luas oleh masyarakat nusantara yang meliputi Indonesia, Malaysia, Singapura, Filipina dan lainnya. Kain sarung banyak digunakan sebagai pakaian ibadah, pakaian adat, pakaian kehormatan hingga pakaian seharihari atau menjadi pelengkap tidur. Sarung juga sering digunakan pada seremoni acara-acara budaya oleh banyak suku di Indonesia bahkan sering pula menjadi hadiah dikalangan kepala-kepala suku.

Salah satu daerah tujuan wisata di provinsi Kalimantan Timur adalah kota Samarinda tepatnya di Kampung Baka, Samarinda Seberang yang memiliki salah satu objek wisata Sarung Tenun Samarinda yang merupakan salah satu objek wisata budaya karena sarung tenun merupakan salah satu warisan sejarah yang bersifat turun temurun, hingga saat ini pun proses pembuatan sarung tenun tetap dilakukan secara tradisional guna menjaga dan melestarikan keberadaanya agar tidak punah, serta dapat di kenal oleh banyak kalangan masyarakat. Sarung tenun sendiri merupakan salah satu produk yang dapat dijadikan sebagai cinderamata atau oleh-oleh bagi para pengunjung yang datang berwisata ke Samarinda Seberang.

Untuk lebih mengenalkan keberadaan serta daya tarik sarung tenun ini diperlukan usaha-usaha serta strategistrategi yang tepat, karena selain daya tarik yang dimiliki, sarung tenun ini juga memiliki daya jual yang besar, apalagi sarung merupakan salah satu produk nyata yang di butuhkan banyak orang dalam banyak kegiatan, dan distribusi barangnya pun lebih cepat di terima banyak orang karena salah satu produk yang berwujud dapat langsung dirasakan manfaat serta wujud barangnya daripada produk yang berbentuk objek wisata.

Namun karena banyaknya produkproduk unggulan yang beredar dan pada masa yang semakin serba canggih dengan berbagai teknologi saat ini, perlahanlahan hasil yang bersifat budaya tradisional pun bisa terlupakan dan nilainilai budaya juga semakin merabun. Dalam hal ini perlu adanya tindakan dari instansi-instansi terkait khususnya pihak Dinas Pariwisata Samarinda untuk tetap mempertahankan serta melestarikan wisata budaya sarung tenun tersebut, dan salah satu cara adalah dengan promosi, Karena pada saat ini promosi terhadap wisata budaya sarung tenun sendiripun masih kurang dan sangat terbatas, apalagi informasi mengenai sarung tenun sendiri masih bersifat simpang siur dari satu pihak ke pihak lainnya, terlebih lagi lokasi yang masih sulit langsung di ketahui banyak orang.

\section{Metode Penelitian}

Penelitian ini dilaksanakan di Lokasi penelitian sarung tenun Samarinda ini terletak di jalan Pangeran Bendahara Gang. Pertenunan Kelurahan Masjid Baqa Kecamatan Samarinda Seberang. Penelitian ini merupakan penelitian yang menggunakan metode penelitian deskriptif kualitatif. Penelitian deskriptif kualitatif didefinisikan sebagai suatu 
proses penelitian dan pemahaman yang berdasarkan pada metodologi yang menyelidiki suatu fenomena social dan masalah manusia yang menghasilkan data deskriptif berupa kata-kata tertulis atau lisan dari orang-orang dan perilaku yang dapat diamati.

Untuk mengumpulkan data-data penulis menggunakan metode pengumpulan data secara observasi langsung ke obyek penelitian, melakukan wawancara dengan pengrajin sarung tenun dan studi pustaka. Data yang telah dikumpulan kemudian dianalisis dengan menggunakan teknik analisa data deskriptif kualitatif dengan pendekatan Analisis SWOT adalah sarana penilaian kondisi eksternal dan aplikasinya terhadap kemampuan internal objek wisata.

\section{Tinjauan Pustaka.}

Pariwisata merupakan suatu perjalanan yang dilakukan seseorang untuk sementara waktu yang diselenggarakan dari suatu tempat ke tempat yang lain dengan meninggalkan tempat semula dan dengan suatu perencanaan atau bukan maksud untuk mencari nafkah di tempat yang dikunjunginya, tetapi semata-mata untuk menikmati kegiatan yang berupa hiburan atau rekreasi untuk memenuhi keinginan yang beraneka ragam.

Menurut Richard Sihite (2000:4647) menjelaskan definisi pariwisata adalah :Suatu perjalanan yang dilakukan orang untuk sementara waktu, yang diselenggarakan dari suatu tempat ke tempat lain meninggalkan tempatnya semula, dengan suatu perencanaan dan dengan maksud bukan untuk berusaha atau mencari nafkah di tempat yang dikunjungi, tetapi semata-mata untuk menikmati kegiatan bertamasya dan rekreasi atau untuk memenuhi keinginan yang beraneka ragam.
Menurut Hunziger dan Krapf dari Swiss dalam Grundriss Der Allgemeinen Femderverkeheslehre, pariwisata adalah: Keseluruhan jaringan gejala - gejala yang berkaitan dengan tinggalnya orang asing disuatu tempat dengan syarat orang tersebut tidak melakukan suatu pekerjaan yang penting (Major Activity) yang memberi keuntungan yang bersifat permanent maupun sementara.

Dari beberapa pengertian diatas dapat disimpulkan bahwa pariwisata adalah perjalanan dari satu tempat ke tempat lain meninggalkan tempat semula untuk sementara waktu tetapi tidak untuk mencari nafkah.

Sementara daya tarik wisata menurut Oka A Yoeti 1985 objek wisata adalah :

Segala sesuatu yang menjadi daya tarik bagi orang untuk mengunjungi suatu daerah tertentu. Sedangkan menurut Nyoman S Pendit, 1994 dalam buku yang berjudul "Ilmu Pariwisata" objek wisata adalah :

Dalam dunia pariwisata segala sesuatu menarik dan yang bernilai untuk dikunjungi dan dilihat, disebut atraksi atau lazim pula dinamakan objek wisata

\section{a. Jenis Objek Wisata}

Seiring dengan perkembangan industri pariwisata, munculah bermacam - macam jenis objek wisata yang lama kelamaan mempunyai cirinya tersendiri. Perkembangan ini bertujuan untuk memenuhi kebutuhan wisatawan yang saat ini melakukan perjalanan wisata berdasarkan alasan dan tujuan yang berbeda - beda.

Menurut Samsuridjal (1997 : 24) mengemukakan bahwa jenis - jenis wisata antara lain:

1.Wisata Rekreasi adalah wisata yang dilakukan orang untuk memanfaatkan waktu libur di luar rumah. Kebanyakan wisata jenis ini dilakukan untuk menikmati keindahan alam. 
2. Wisata Bahari adalah wisata dengan objek kawasan laut misalnya menyelam, berselancar, berlayar, memancing dan lain - lain.

3. Wisata alam adalah wisata dengan objek alam. Objek gunung yang tinggi, gua, sungai yang deras, tebing terjal. Pada umumnya peminat objek ini adalah para remaja dan petualang.

4. Wisata Budaya adalah wisata yang menawarkan objek yang berupa tradisi dan budaya serta adapt istiadat masyarakat yang unik.

5. Wisata Olahraga adalah wisata yang dilakukan dengan tujuan pertandingan dan meningkatkan prestasi olah raga.

6. Wisata Bisnis adalah perjalanan yang dilakukan untuk tujuan bisnis. Isata jenis ini membutuhkan sarana penunjang bisnis yang baik.

7. Wisata Konvensi adalah wisata yang dilakukan ke suatu negara untuk keperluan rapat atay siding

8. Wisata jenis lain adalah keinginan dan ketertarikan masyarakat beraneka ragam.

Perkembangan jenis wisata juga semakain banyak. Kini mulai popular dengan apa yang disebut dengan wisata sejarah, arkelogi, berburu, safarai, fotografi, bulan madu dan sebagainya.

\section{b. Strategi Pemasaran}

Pada dasarnya strategi merupakan alat unuk mencapai suatu tujuan, dengan strategi tersebut perusahaan menetapkan cara untuk mencapai sasaran yang telah direncanakan oleh karena itu setiap manajer perusahaan melalui program khusus yang diterapkan secara efisien dan dapat diperbaiki apabila gagal mencapai tujuan.

Adapun pengertian strategi menurut Gluek (1990) strategi adalah : Sebuah rencana yang disatukan luas dan terintegrasi yang menghubungkan keunggulan strategi perusahaan dengan tentang lingkungan dan yang dirancang untuk memastikan bahwa tujuan utama perusahaan itu dapat dicapai melalui pelaksanaan yang tepat oleh organisasi.

Sedangkan yang dimaksud dengan Asosiasi Manajemen Amerika (AMA), bahwa "pemasaran adalah pengidentifikasian atau penciptaan kebutuhan pelanggan, lalu mendorong dan mengkoordinasi pemanfaatan semua fungsi yang ada di dalam suatu usaha sehingga dapat memenuhi kebutuhan itu dengan menyenangkan pihak pembeli dan penjual yang terlibat", sedangakan menurut Tjiptono (2002:7) memberikan definisi pemasaran adalah: "Suatu proses sosial dan manajerial dimana individu atau kelompok mendapatkan apa yang mereka butuhkan dan inginkan melalui penciptaan, pewarnaan, dan pertukaran segala sesuatu yang bernilai dengan orang atau kelompok lain.

Bauran pemasaran adalah satu set variabel pemasaran yang bisa dikendalikan, berpadu secara kuat untuk menghasilkan reaksi yang diinginkan oleh target pasar. Variabel pemasaran untuk pusat informasi dapat digolongkan ke dalam 4 grup variabel yang menurut Kotler dikenal dengan 4C yaitu; client, cost, convenience, dan communication.

Unsur-unsur bauran pemasaran sering disebut sebagai 'empat $\mathrm{P}^{\prime}$ yaitu: product,price,place dan promotion. Dalam melakukan strategi pemasaran juga di perlukan suatu tindakan awal yakni melakukan segmentasi pasar yang merupakan suatu usaha untuk meningkatkan ketepatan dari pemasaran itu sendiri, dan dalam melakukan segmentasi pasar ini terdapat tiga tahap penting yang harus dilakukan yaitu : survey, analisis, dan pembentukan

Pemasaran pariwisata (tourism marketing) adalah suatu sistem dan koordinasi yang dilaksanakan sebagai suatu kebijakan bagi perusahaan-perusahaan yang bergerak di bidang kepariwisataan, baik milik swasta maupun pemerintah, dalam ruang lingkup 
lokal, regional, nasional dan internasional untuk dapat mencapai kepuasan wisatawan dengan memperoleh keuntungan yang wajar (Yoety 1990:30). Bauran Pemasaran Jasa 7P:

1. Produk (Product), merupakan kombinasi barang dan jasa yang ditawarkan oleh seseorang atau lembaga untuk memenuhi kebutuhan pasar.

2. Harga (Price), adalah nilai suatu barang atau jasa yang diukur dengan sejumlah uang dimana berdasarkan nilai tersebut seseorang atau perusahaan bersedia melepaskan barang atau jasa yang dimiliki kepada pihak lain.

3. Tempat/distribusi (Place), adalah berbagai kegiatan perusahaan untuk membuat produk yang dihasilkan/dijual terjangkau dan tersedia bagi pasar sasaran. Tempat meliputi antara lain channels, coverage, assortments, locations, inventory, and transport.

4. Promosi

(Promotion), adalah komunikasi yang persuasif, mengajak, mendesak, membujuk, meyakinkan. Ciri dari komunikasi yang persuasif (komunikasi) adalah : Ada komunikator yang secara terencana mengatur berita dan cara penyampaiannya untuk mendapatkan akibat tertentu dalam sikap dan tingkah laku si penerima.

5. Orang (People), adalah Seluruh aktor manusia yang mengambil bagian dalam delivery jasa dan turut mempengaruhi persepsi pembeli; yaitu, personel perusahaan, pelanggan dan pelanggan lain dalam lingkungan jasa.

6. Bukti Fisik (Physical Evidence), yaitu Lingkungan tempat jasa dideliver dan tempat perusahaan berinteraksi dengan pelanggan, beserta semua komponen tangible
17

yang memfasilitasi kinerja dan komunikasi jasa.

7. Proses (Process), yaitu semua prosedur aktual, mekanisme dan aliran

aktivitas dengan mana jasa disampaikan yang merupakan sistem penyajian atas operasi jasa.

Sementara itu, promosi merupakan salah satu bagian dari kegiatan pemasaran sebagai sarana untuk mencapai tujuan yang diinginkan dalam suatu produk, dalam prosesnya promosi hanya dilakukan oleh satu pihak dan informasi yang disampaikan hanya bersifat searah (oneway communication). Biasanya kegiatan promosi ini merupakan usaha atau strategi untuk mendukung suatu kegiatan pemasaran, baik dilakukan oleh pemerintah maupun oleh pihak swasta atau perusahaan. Artinya, promosi merupakan aktivitas yang berusaha menyebarkan informasi untuk mempengaruhi, membujuk atau meningkatkan sasaran agar bersedia menerima,membeli, dan loyal terhadap produk yang ditawarkan oleh perusahaan yang bersangkutan.

Sesuai dengan pendapat Onong Uchana Effendi, 1997:7 pada bukunya yang berjudul Ilmu Komunikasi, teori dan praktek mengatakan "Dalam kegiatan promosi diperlukan strategi-strategi yang tepat agar kegiatan promosi yang dilakukan sesuai dengan target yang ditentukan, strategi promosi ini berkaitan dengan masalah perencanaan, pelaksanaan, pengendaliankomunikasi persuasif dengan pelanggan, dan adanya evaluasi terhadap strategi promosi yang telah dilaksanakan". Sedangkan menurut Ilham Prisgunanto, 2006:31 dalam bukunya yang berjudul Komunikasi Pemasaran Strategi dan Taktik bahwa "Strategi promosi terdiri dari beberapa komponen, oleh karena itu manejemen akan memperoleh keuntungan dengan 
menggabungkan komponen promosi ke dalam suatu strategi terpadu untuk berkomunikasi dengan para pembeli dan orang lain yang mempengaruhi keputusan membeli".

Rencana promosi, dalam rencana promosi terdapat tujuh panduan dalam Implementasinya, yaitu (Ilham Prisgunanto, 2006:31-32 Komunikasi Pemasaran Startegi dan Taktik):

1) Memilah-milah karakteristik khalayak

2) (segmentasi pelanggan dari bank data).

2) Menemukan titik konta (media) komunikasi yang paling menyentuh khalayak (contact point) management).

3) Menemukan konsep penduduk dalam benak konsumen (brand network.

4) Menentukan sasaran dan strategi komunikasi

5)Meramu teknik-teknik atau bauran pemasaran (4P)

6)Mendayagunakan taktik komunikasi pemasaran seperti iklan, promosi, penjualan, kehumasan, pemasaran langsung, komunikasi getok-tular (wortof- mouth communication), dan sebagainya.

Sedangkan strategi promosi terdiri dari sepuluh langkah yang dimulai dari dan berakhir pada perspektif konsumen, yaitu (Ilham Prisgunanto, 2006:35):

1) Menelusuri persepsi, alam pikiran dan perilaku konsumen terhadap produk (consumer buying incentive)

2) Membandingkan realitas produk dengan persepsi konsumen

3) Mengenali situasi persaingan

4) Mengetahui manfaat kunci bagi konsumen (consumer benefit)
5) Merancang program komunikasi pemasaran

6) Menciptakan keunikan dan identitas merek

7) Menetapkan sasaran dan tindakan komunikasi

8) Membentuk persepsi di benak khalayak

9) Menemukan titik kontak (media) yang paling sesuai.

10) Menyusun daftar riset yang bisa dilakukan untuk masa mendatang.

Dalam rencana promosi dan strategi promosi terdapat saluran-saluran promosi yang utama, sehingga dalam penetapan tahapan strategis yang harus dilakukan sebagai langkah utama dalam melaksanakan kegiatan promosi harus melalui saluran promosi atau promotion mix. Terdapat beberapa saluran promosi yang utama atau promotion mix (dalam Kotler, 2002: 626-630) yaitu:

\section{Advertising (periklanan)}

Peran periklanan dalam pemasaran jasa adalah untuk membangun kesadaran akan jasa, untuk membantu membujuk pelanggan supaya membeli, dan untuk mendeferensikan jasa dan penawaran jasa yang lain. Karena sifat jasa yang tak berwujud. Maka sulit untuk mempromosikannya, untuk itulah instansi memilih media berwujud untuk sarana promosi. Media sebagai saluran promosi tersebut diklasifikasikan menjadi dua, yaitu: media above the line dan media below the line. Media above the line (media lini atas) meliputi media cetak, misalnya 
surat kabar dan majalah, media elektronik, misalnya radio dan televisi, media bioskop, serta media luar ruang, misalnya poster, baliho, dan pamflet. Untuk media below the line (media lini bawah), misalnya direct mail, pameran (exhibition), peragaan (display), point of sale, selebaran, poster, leaflet, brosur, dan lainlain.

\section{Sales Promotion (promosi} penjualan)

Promosi penjualan mempunyai beberapa karakteristik yang menonjol, yaitu menarik perhatian, memberikan informasi yang bernilai bagi konsumen, memberikan kemudahan, bersifat membujuk, dan menggerakkan konsumen untuk terlibat dalam transaksi. masyarakat)

3. Public Relations (hubungan Peranan public relations adalah untuk melakukan promosi halhal yang menyangkut kepariwisataan, termasuk aspek yang berkaitan dengan tourism, pariwisata budaya, obyek wisata, dan lain-lain. Beberapa alat yang sering dipakai dalam merancang program public relations adalah: Publikasi, misalnya press release, laporan tahunan, brosurbrosur, poster, artikel, laporan karyawan, Peristiwa (event), termasuk konferensi pers, seminar, pidato dan koferensi, Hubungan dengan investor

yang ditujukan untuk memperoleh dukungan investor, pameran (exhibition).

\section{Personal selling (penjualan} pribadi)

Personal selling memiliki peran yang vital dalam jasa, dikarenakan kebanyakan bisnis jasa melibatkan interaksi personal antara penyedia jasa dan pelanggan. Keunggulan personal selling adalah mampu menciptakan kontak dengan pelanggan, meningkatkan hubungan denga pelanggan, dan dapat menciptakan penjualan silang, yakni penjual dapat menawarkan produk produk jasa lain kepada pelanggan. Contoh kegiatan personal selling adalah, presentasi penjualan, pertemuan penjualan, insentif, pameran perdagangan, agen asuransi, pialang saham, petugas layanan nasabah, pramugari, dan lainlain. Tujuan personal selling dalam pariwisata adalah adanya tanggapan dan saran dari masyarakat mengenai apa yang menjadi kesukaan obyek-obyek wisata.

5. Direct marketing (promosi langsung).

Elemen media promosi yang terakhir adalah direct marketing yang langsung berinteraksi dengan para calon konsumen. Direct marketing dikenal dengan metode promosi yang rendah biaya dan efektif untuk berkomunikasi dengan pelanggan perusahaan. Beberapa contoh pemasaran melalui direct marketing antara lain: catalog, TV media, melalui telepon, dan lain-lain.

\section{Hasil dan Pembahasan}

Sarung tenun
terletak di $\begin{array}{r}\text { Samarinda } \\ \text { Pangeran }\end{array}$
$\begin{array}{lr}\text { Bendahara gang Pertenunan } \\ \text { Samarinda seberang di hilir sungai }\end{array}$
Mahakam kota Samarinda
Provinsi Kalimantan Timur. Sarug
tenun Samarinda merupakan usaha
turun - temurun keluarga dan para
pengrajinnya sendiri kebanyakan
dikerjakan oleh kaum wanita yang


mana hasilnya secara langsung dapat menambah perekonomian keluarga dan secara tidak langsung menyalurkan keahlian mereka di bidang kerajinan tangan ini sendiri sebagai penenun. Pertenunan sarung ini sendiri yang mana sebagai kerajinan tangan mempunyai dua jenis alat pertenunan, yaitu terdiri dari tenun tangan/gedokan dan alat tenun bukan mesin (ATBM), serta mempunyai benang sebagai bahan dasar yang merupakan atau menjadi ciri khas tersendiri dalam menenun sarung tersebut antara lain terdiri dari benang Sutera Alam (ulat Sutera dari dalam Negeri) dan benang sutera (dari luar Negeri).adapun tahapan proses dari pengerjaan penenunan sarung ini sendiri yaitu mencelupkan benang yang terdiri dari berbagai warna yang diperlukan, penyusunan corak dan motif yang diinginkan penenun sarung.

Kondisi bangunan secara fisik objek wisata sarung tenun Samarinda merupakan rumah rumah biasa atau rumah tempat tinggal/hunian masyarakat dan didepan rumah terdapat alat tenun I gedokan yang dipakai untuk membuat sarung tenun. Kondisi akses untuk menuju ke objek wisata cukup sulit karena objek wisata sendiri tidak terlihat seperti objek wisata karena terlihat seperti rumah hunian biasa selain itu hanya terdapat papan nama di pintu masuk objek wisata. Selain itu tidak ada papan petunjuk lain dan karena objek wisata terletak jauh dari pusat kota wisatawan sulit untuk mencapainya. Sealin itu jalannya yang sempit sehingga wisatawan mengalami kesulitan untuk berkunjug kedaerah objek wisata.

Macam - macam corak sarung tenun Samarinda yaitu corak sarung Hatta, corak Soeharto, corak merica, corak pulu, corak asepulu bolong, corak cokka manippi, corak burairah, corak billa takkajo, corak ayam corak siparapre, corak taba hijau dan lain-lain.

\section{a. Strategi Promosi Sarung Tenun Samarinda Sebagai Produk Wisata Budaya}

Dalam rencana strategi promosi yang dilakukan oleh Dinas Pariwisata terdapat saluran promosi yang utama yang dijadikan saluran promosi untuk menjadi produk unggulan. Beberapa saluran promosi yaitu: periklanan (advertising), personal selling, public relation dan sales promotion merupakan pilihan bagi Dinas Pariwisata untuk memilih salah satu saluran yang sesuai dengan situasi kondisi masyarakat kecamatan Samarinda Seberang. Berikut ini adalah strategi yang dilakukan oleh Dinas Pariwisata:

1. Mengikuti pameran Mengikuti setiap pameran yang diadakan oleh kota, provinsi, maupun yang ada di luar negeri.

2. Menayangkan promosi lewat media elektronik seperti :

a) Pihak Dinas Pariwisata menayangkan promosi Sarung Tenun Samarinda menggunakan media elektronik yaitu berupa Radio.

b) Pihak dinas pariwisata menayangkan promosi sarung tenun Saamrinda menggunakan media Televisi.

3. Membuat Buku Saku Membuat buku saku tentang sarung tenun dimaksudkan pihak dinas 
pemerintah untuk memperkenalkan sarung tenun Samarinda.

4. Membuat Brosur Pihak dinas pariwisata membuat brosur khusus mengenai sarung tenun. Kemudian brosur ini di bagikan melalui pameran, hotel. Travel agent, dan lain - lain.

\section{b. Identifikasi SWOT}

Untuk dapat menyusun strategi yang tepat dalam rangka mencapai sasaran atau strategi yang telah diterapkan, maka perlu dilakukan faktor-faktor intern dan ekstern yang dapat mempengaruhi kunjungan pada khususnya dan pada perkembangan industri pariwisata pada umumnya. Analisis semacam ini ditujukan untuk melakukan identifikasi kekuatankekuatan ( strength) dan kelemahankelemahan( weaknesses ) yang ada dalam industri pariwisata Indonesia, dalam menghadapi kesempatankesempatan ( opportunities ) yang ada serta ancaman-ancaman ( threats ) yang disebut sebagai analisis SWOT. Pengamatan dengan analisis SWOT dapat juga memberikan gambaran yang lebih jelas mengenai objek wisata sarung tenun Samarinda sehingga dapat diketahui potensi objek wisata budaya sarung tenun Samarinda secara lebih jelas.

Hasil Analisis SWOT sarung tenun Samarinda dapat dilihat pada table berikut ini:

Tabel I. Analisis SWOT

\begin{tabular}{|c|c|}
\hline Analisis & Hasil Analisis \\
\hline $\begin{array}{l}\text { Strength(Keku } \\
\text { atan) }\end{array}$ & $\begin{array}{l}\text { 1. Kualita } \\
\text { s } \\
\text { sarung } \\
\text { tenun }\end{array}$ \\
\hline
\end{tabular}

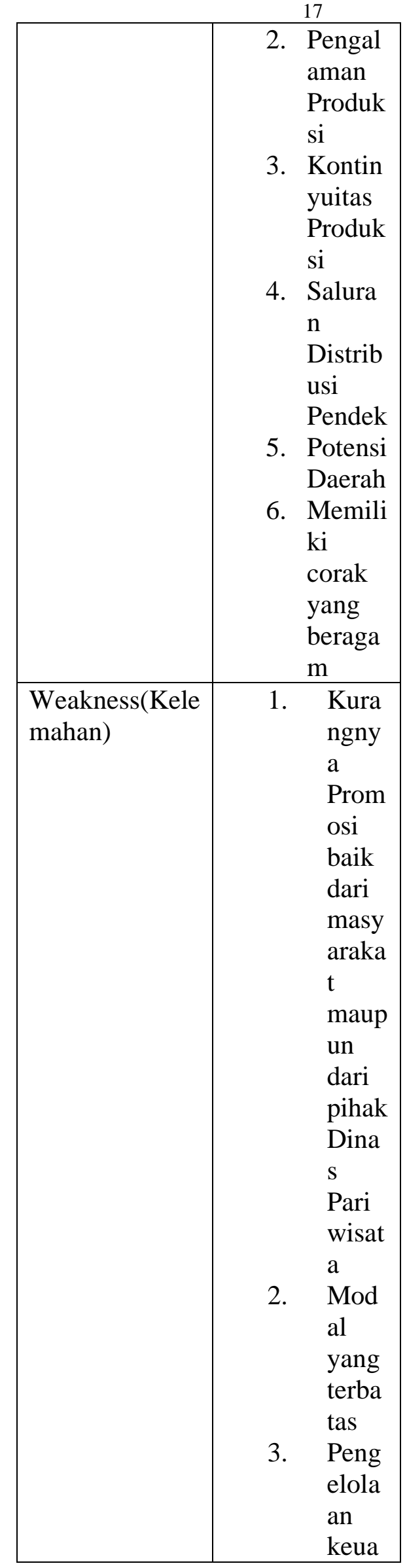




\begin{tabular}{|c|c|c|}
\hline & 4. & $\begin{array}{l}\text { ngan } \\
\text { / } \\
\text { pemb } \\
\text { ukua } \\
\mathrm{n} \\
\text { belu } \\
\mathrm{m} \\
\text { tersu } \\
\text { sun } \\
\text { rapi } \\
\text { Peng } \\
\text { rajin } \\
\text { kura } \\
\text { ng } \\
\text { fokus } \\
\text { dala } \\
\text { m } \\
\text { kegia } \\
\text { tan } \\
\text { usah } \\
\text { a. }\end{array}$ \\
\hline $\begin{array}{l}\text { Oppurtunities( } \\
\text { Peluang) }\end{array}$ & $\begin{array}{l}1 . \\
2 . \\
\\
3 . \\
4 . \\
5 . \\
\\
5 .\end{array}$ & $\begin{array}{l}\text { Pembi } \\
\text { naan } \\
\text { dan } \\
\text { pelatih } \\
\text { an } \\
\text { Bantua } \\
\text { n } \\
\text { modal } \\
\text { dengan } \\
\text { subsidi } \\
\text { bunga } \\
\text { Event } \\
\text { pamera } \\
\text { n } \\
\text { Perke } \\
\text { mbang } \\
\text { an } \\
\text { objek } \\
\text { wisata } \\
\text { Hubun } \\
\text { gan } \\
\text { baik } \\
\text { dengan } \\
\text { pemas } \\
\text { ok } \\
\text { Adany } \\
\text { a }\end{array}$ \\
\hline
\end{tabular}

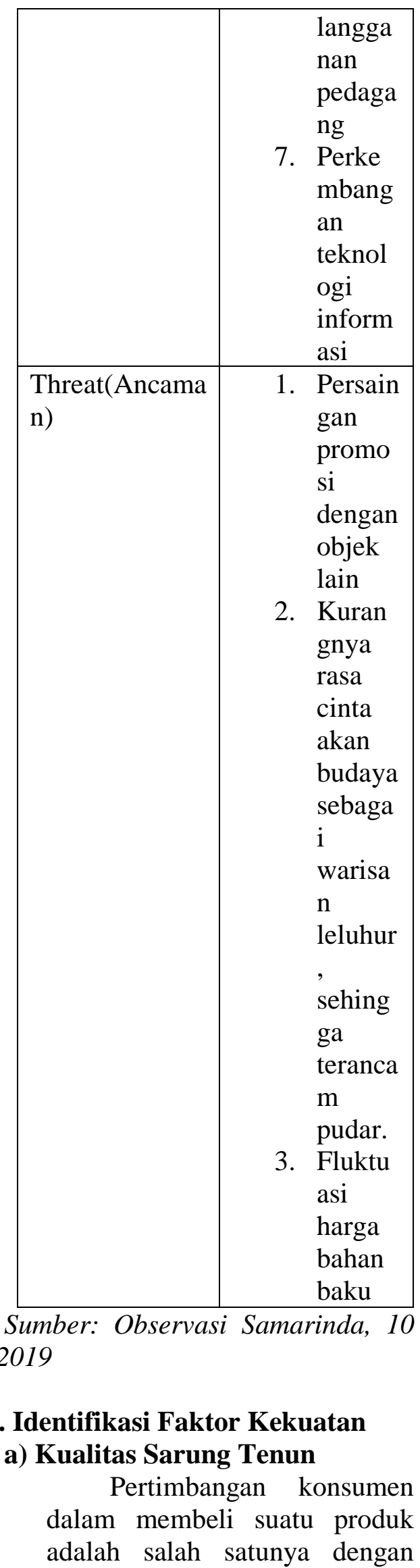


melihat kualitas produk yang akan digunakan. Produk sarung tenun yang ada di Samarinda ini menunujukan kulitas yang sesuai dengan permintaan pasar. Hal ini di wujudkan dengan keberlangsungan usaha sarung tenun hingga sekarang dan permintaan yang cukup stabil. Dalam pelaksanaan penenunan dilakukan seleksi bahan baku sehingga berpengaruh pada kualitas sarung tenun yang dihasilkan. Penilaian kualitas pada produk sarung tenun lebih ditekankan pada motif atau corak, kecerahan dan kombinasi warna yang bagus sehingga terlihat tidak kusam dan menarik.

\section{b) Pengalaman produksi}

Pengalaman produksi
dalam menenun sangat
diperlukan untuk menunjang
sarung tenun yang dihasilkan
memiliki kualitas yang baik.
Semakin lama mereka mereka
mengusahakan sarung tenun
semakin membuat mereka
terlatih dan terampil dalam
menenun sarung Samarinda.
Menenun sarung merupakan pekerjaan yang cukup rumit dan membutuhkan ketlatenan dari para penenun. Salah satu hal yang mempengaruhi hasil tenunan adalah keterampilan pengrajin dalam menenun. Dengan keterampilan pengrajin secara turun - temurun serta pengalaman yang cukup lama dalam mengelola usaha sehingga mampu menjadikan usaha sarung tenun ini dapat bertahan dan berkembang sampai sekarang.

\section{c) Kontinyuitas Produksi}

Selama ini, para pengrajin senatiasa menjaga kontinyuitas produksinya. Didukug dengan pasokan bahan baku yang terjamin serta pengrajin senantiasa menenun di waktu waktu luangnya menjadikan ketersediaan sarung tenun ini akan senantiasa ada. Selain itu, permintaan konumen yang cukup stabil juga mempengaruhi pengrajin untuk menjaga kontinyuitas produksi sarung tenunnya.

\section{d) Saluran Distribusi Pendek}

Distribusi merupakan proses penyampaian barang dan jasa dari produsen ke konsumen. Adanya ketersedian alat pengangkutan dan pedagang pengumpul maupun tenaga penjual lainnya membuat produk sampai ke tangan konsumen sehingga dapat membantu dalam penyaluran produk sarung tenun dari produsen kepada konsumen.

\section{e) Potensi Daerah}

Sarung tenun Samarinda merupakan salah satu usaha potensial di Samarinda. Hal ini di dukung kemampuan sumber daya manusia untuk menenun serta dengan adanya benang sutera sebagai bahan pokok sarung tenun Samarinda. Dengan adanya penjual benang sutera maka akan menjamin pasokan bahan baku yang dibutuhkan dalam produksi sarung tenun Samarinda. Oleh karena itu sampai saat ini masih bnayak para pengrajin yang mengusahakan sarung tenun Samarinda sebagai salah satu poensi daerah, maka usaha 
sarung tenun mempunyai hak mendapat perhatian pemerintah dalam pengembangan usaha sarung tenun Samarinda. Pembinaan dan pelatihan yang dilakukan pemeintah menunjang kemampuan teknis pengusaha serta kemampuan manajemen mereka. Selama ini pemerintah telah melakukan pelatihan kepada pelaku usaha serta memberikan bantuan alat dan bahan baku yang dibutuhkan. Sehingga peluang ini dapat dimanfaatkan oleh pengrajin sarung tenun Samarinda untuk peningkatan dan pengembangan usaha mereka.

\section{f) Memiliki berbagai macam corak}

Sekarang ini sebagai generasi penerus dari sarung tenun Samarinda mereka juga mendesain berbagai macam corak yaitu corak Hatta, corak pengantin, corak merica, corak Soeharto, corak pulu,corak bolong, corak cokka mannipi, corak burairah, corak billa takkajo, corak ayam palopo (sirat-sirat bambu), corak garanso, corak catur, corak mammario. Sebagai generasi penerus mereka selalu berusaha untuk meningkatkan kualitas produksi dan mutu agar bisa brsaing dengan produk dari daerah lain utamanya dalam negeri.

\section{b. Identifikasi Faktor Kelemahan}

a) Kurangnya Promosi baik dari masyarakat maupun dari pihak Dinas Pariwisata

Promosi sarung tenun Samarinda selama ini yang dilakukan oleh pengrajin adalah dengan media mulut ke mulut. Para pengrajin belum memanfaatkan kemajuan teknologi yang berkembang dalam mempromosikan produk mereka. Selain karena kertebatasan kemampuan dan pengetahuan dalam mengakses teknologi baru mempengaruhi pengrajin untuk tetap mempertahankan

metodepromosi mereka.

Sedangkan pemerintah dinas pariwisata sementara ini hanya melakukan promosi lewat pameran - pameran yang diadakan di samarinda ataupun diluar kota Samarinda serta lewat website tetapi website ini bergabung dengan website DISPERINDAG Samarinda, promosi lewat televisi, radio lokal, dan buku saku.

b) Modal Terbatas

Salah satu hal yang menjadi sorotan dalam setiap usaha adalah masalah modal. Pada usaha sarung tenun Samarinda modal didaptkan dari kekayaan pengrajin sendiri. Adanya peluang bantuan modal dari pemerintah seringkali para pengrajin sulit para pengrajin sulit mendapatkan karena prosedur yang masih cukup rumit bagi kalangan pengrajin kecil. Oleh karena itu, pengrajin menjalankan usaha ini dengan modal mandiri yang seadanya. Dengan adanya keterbatasan modal maka pengrajin kesulitan dalam mengembagkan usaha serta termasuk dalam melakukan inovasi pemasaran anyaman tikar.

c) Pengelolaan Keuangan / Pembukuan Belum tersusun rapi 
Seperti halnya denga usaha kecil yang lain, salah satu kelemahan yang sering di temui adalah terkait pembukuan keuangan usaha yang belum tersusun rapi. Pengrajin hanya mengadministrasikan keuangan dalam usaha mereka secara abstrak tanpa dituliskan dalam pembukuan usaha secara rapi. Hal ini menyebabkan informasi - informasi yang seharusnya dapat dimanfaat sebagai pertimbangan dalam menentukan kebijakan selanjutnya tidak terinventaris secara sempurna. Oleh karena itu pengrajin tidak dapat mengkalkulasi keuangan usaha secara tepat dan akurat.

d) Pengrajin Kurang Fokus alam Kegiatan Usaha

Rumitnya proses sarung tenun Samarinda serta kurangnya fokusnya pengrajin dalam mengelola usaha menyebabkan waktu yang dibutuhkan dalam menyelesaikan sarung tenun cukup lama selai itu, karena pengrajin menjadikan pekerjaan menenun sebagai pekerjaan sampingan karena pengrajin sarung tenun umumnya wanita dan ibu rumah tangga, sehingga alokasi waktu yang dicurahkan untuk mengannyam adalah antara 2-4 jam setiap hari.

\section{c. Identifikasi Faktor Peluang}

a) Pembinaan dan Pelatihan

Perhatian Pemerintah dalam upaya mengembangkan usaha kecil menengah yang ada di Samarinda adalah dengan menggiatkan pelatihan dan pembinaan kepada pengrajin sehingga kemampuan teknis ataupun kreativitas pengrajin juga meningkat. Selain itu

pembinaan yang dilakukan juga bertujuan untuk perbaikan manajemen UKM, sebagai salah satu industri kecil yang mendapat perhatian pemerintah untuk memperoleh pelatihan dan pembinaan adalah industri industri sarung tenun Samarinda dari bahan baku benang sutera.

b) Bantuan Modal dengan Subsidi Bunga.

Langkah Pemerintah dalam membantu masyarakat golongan ekonomi lemah dalam mempertahankan usaha mereka adalah melalui program bantuan modal dengan subsidi bunga. Hal ini merupakan wujud perhatian Pemerintah dalam pemberdayaan usaha kecil menengah yang ada di Samarinda program ini dilaksanakan agar pengrajin mendapatkan tambahan modal dengan tingkat bunga yang lebih rendah daripada lembaga keuangan lainnya seperti bank. Untuk lebih memudahkan para pengrajin dalam mengakses program ini, maka pemerintah senantiasa melakukan perbaikan sistem dalam aturan peminjaman sehingga program ini data dirasakan manfaatnya oleh masyarakat pelaku usaha kecil menengah yang membutuhkan tambahan modal.

c) Event Pameran

Salah satu rangkah
promosi yang $\begin{array}{r}\text { dapat } \\ \text { dalam }\end{array}$
dimanfaatkan
memperkenalkan produk -
produk kabupaten adalah dengan
adanya event pameran. Pameran
atau mengikuti pameran yang
diselenggarakan di kota lain.
Dalam rangkaian promosi
tersebut, pemerintah juga
membuat brosur mengenai


produk - produk sarng tenun Samarinda. Dengan mengoptimalkan langkah ini diharapkan mampu meningkatkanpemasaran produk - produk sarung tenun di Samarinda sehingga mampu mengembangkan usaha sarung tenun.

d) Perkembangan Objek Wisata

Wilayah kota Samarinda mempunyai beberapa objrk wisata yang potensial untuk dikembangkan guna menarik wisatawan yang dating ke Samarinda. Pengembangan di bidang pariwisata merupakan salah satu strategi yang dapat dimanfaatkan Pemerintah kota Samarinda untuk meningkatkan pendapatan daerah. Adanya perkembangan objek wisata merupakan salah satu peluang yang dapat dimanfaatkan oleh para pengrajin sarung tenun untuk meningkatkan pemasaran produk mereka sebagai salah satu souvenir para wisatawan dari tempat wisata.

e) Hubungan Baik Dengan Pemasok

Adanya hubungan yang baik dengan pemasok menimbulkan keuntungan bagi pengusaha. Salah satu bentuk keuntungan yang diperoleh adalah ketika pengrajin membutuhkan bahan baku maka pemasok akan segara memasok bahan baku benang sutera yang dibutuhkan pengusaha. Selain itu, karena adanya rasa kepercayaan yang sudah terjalin antara pemasok dengan pengrajin maka pengrajin lebih mudah dalam mendapatkan bahan baku benang sutera berkualitas yang baik. f) Adanya Langganan Pedagang

Dalam hal pemasaran produk, pengrajin mempunyai langganan pedagang pengumpul. Oleh karena itu, jika tidak ada pembeli yang datang langsung ke tempat pengrajin maka pengrajin dapat menjualnya pedagang pengumpul langganan mereka di berbagai tempat di citra niaga toko penjual souvenir bahkan hingga kepulau jawa. Dengan adanya langganan pedagang yang ada di berbagai tempat penjual souvenir, pengrajin lebih mudah dalam menjual produknya serta adanya keterjaminan produk mereka terjual.

g) Perkembangan Teknologi Informasi

Kemajuan zaman yang semakin tinggi mendorong perkembangan peradaban manusia yang kea rah modern. Hal ini berdampak pada perkembangan teknologi yang digunakan manusia dalam memenuhi kebutuhannya. Salah satu bentuk kemajuan terlihat pada teknologi informasi yang semakin canggih. Dengan kecanggihan teknologi informasi dapat memfasilitasi manusia untuk semakin cepat berkomunikasi dalam ruang lingkup yang lebih luas dalam waktu yang singkat.

Adanya perkembangan teknologi informasi merupakan peluang yang dapat dimanfaatkan para pengrajin dalam meningkatkan pemasaran produk mereka. Salah satu pemanfaatannya untuk melaksanakan fungsi pemasaran produk baik untuk promosi 
maupun transaksi. Selain itu juga mempermudah pengrajin mengakses informasi mengenai usaha mereka sehingga dapat dijadikan sumber inspirasi dalam mengelola usaha. Oleh karena itu dalam penerapanya para pengrajin harus menentukan segmen pasar yang akan dituju sehingga jelas sasaran promosi yang akan dilakukan.

\section{d. Identifikasi Faktor Ancaman}

a) Persaingan Promosi Dengan Objek Lain

\begin{tabular}{ccc}
\multicolumn{2}{c}{ Persaingan } & dalam \\
promosi suatu objek & wisata
\end{tabular} merupakan hal yang tidak terhidarkan. Begitu pula dalam promosi sarung tenun Samarinda banyaknya pengrajin yang menghasilkan kerajinan sarung tenun menuntut para pengrajin harus mampu bersaing agar dapat mempertahankan usahanya.

b) Fluktuasi Harga Bahan Baku Benang sutera mempunyai masa panen. Jika musim kemarau dan sesekali hujan baru musim panen. Sehingga pedagang bisa jadi tidak mempunyai stok banang sutera. Hal ini menyebabkan fluktuasi harga antara banyak pedagang yang menjual dan tidak stok enang sutera. Hal ini cukup mempengaruhi keberjalanan usaha sarung tenun Samarinda sehingga pengrajin harus berusaha mengambil kebijakan yang tepat agar tetap mampu menjual sarung tenun dengan harga yang stabil.

c) Kurangnya Rasa Cinta Akan Budaya Sebagai Warisan Leluhur, SehinggaTerancam Punah.
17

Sering dengan kemajuan teknologi, ilmu pengetahuan dan gaya hidup yang semakin pesat, kebudayaan yang merupakan warisan dari leluhur kita dan merupakan suatu cirri khas dari suatu daerah, kian lama kian hilang dan memudar dari negara republik ini. Anak muda sekarang banyak yang terpengaruh akan modernisasi dan globalisasi, mulai dari gaya berpakaiaan hingga gaya dalam berbicara maupun makan. Sehingga banyak anak uda zaman sekarang yang kurang peduli bahkan tidak peduli akan kebudayaan kita ini.

Tujuan ini untuk mengetahui objek wisata sarung tenun Samarinda sehingga dapat diketahui arahan yang tepat untuk kegiatan strategi promosi berdasarkan potensi yang ada, metode analisis yang digunakan adalah teknik analisis SWOT, yaitu analisis dengan memperhatikan potensi berupa kekuatan dan peluang tanpa mengabaikan kelemahan dan ancaman sebagai acuan usaha strategi promosi objek wisata tersebut. Dengan mengetahui kekuatan dan peluang yang dimiliki sebagai factor pendukung usaha strategi promosi sarung tenun Samarinda serta dengan memperhatikan kelemahan dan ancaman yang dapat menghambat usaha tersebut diharapkan nantinya langkah atau usaha promosi yangakan direncanakan merupakan rencana yang tepat guna dan berhasil.

Sumber : Analisis Data Primer 


\begin{abstract}
Sebagaimana telah dilakukan identifikasi sarung tenun Samarinda memiliki beberapa faktor yaitu faktor internal ( kekuatan dan kelemahan ) dan eksternal ( peluang dan ancaman ) yang kemudian di susun menjadi matriks SWOT, dimana pengelola dapat memanfaatkan kekuatan secara maksimal untuk mengantisipasi ancaman yang akan muncul, meminimalkan kelemahan untuk menghindari ancaman. Secara keseluruhan dari analisis matriks SWOT dapat disimpulkan sebagai berikut :
\end{abstract}

\section{Strategi $\mathbf{S}-\mathbf{O}$}

Strategi S - O (Strength Oppurtunity) atau strategi kekuatan peluang merupakan strategi yang menggunakan kekuatan internal untuk memanfaatkan peluang eksternal. Alternative strategi $\mathrm{S}-\mathrm{O}$ yang dapat dirumuskan adalah:

a) Meningkatkan kualitas SDM pengrajin dalam rangka meningkat daya saing produk serta memperkuat jejaring permodalan, promosi, dan pelanggan.

Pelaksanaan strategi ini didukung dengan adanya kekuatan berupa pengalaman usaha yang menjadikan pengrajin mempunyai wawasaan dan pengetahuan mengenai usaha yang dijalankan. Selain juga, dengan kualitas sarung tenun yang didukung oleh potensi daerah dalam menyediakan bahan baku sert tenaga kerja yang terampil. Adanya peluang perhatian dari kota Samarinda terhadap usaha kecil menengah yang diwujudkan melalui pembinaan dan pelatihan serta adanya fasilitas penunjang pemberdayaan usaha kecil menengah yang ada dikota Samarinda. Kekuatan yang dimiliki tersebut diharapkan mampu memanfaatkan peluang - peluang yang ada dalam meningkatkan pemasaran produk sarung tenun Samarinda.

b) Menjaga hubungan baik dengan pemasok untuk menjamin kontinyuitas bahan baku.

Salah satu relasi yang perlu diperhatikan oleh pengrajin dalam menjalankan usahanya adalah pemasok bahan baku. Hubungan yang baik antara pengrajin dengan pemasok bahan baku akan berpengaruh pada ketersediaan dan kualitas bahan baku untuk produksi sarung tenun. Oleh karena itu, upaya pengrajin untuk menjaga hubungan baik dengan pemasok akan mempengaruhi kualitas sarung tenun serta kontinyuitas produksi sehingga akan menjaga loyalitas para pelanggan dalam menerima produk mereka.

\section{Strategi $\mathbf{W}-\mathbf{O}$}

Strategi W - O (WeaknessOpportunity) atau strategi kelemahan peluang merupakan strategi untuk meminimalkan kelemahan yang ada untuk memanfaatkan peluang eksternal. Alternatif strategi W-O yang dapat dirimuskan adalah:

a) Optimalisasi penggunaan berbagai media dalam meningkatkan promosi.

Salah satu kelemahan pengrajin dalam promosi sarung tenun Samarinda keterbatasan promosi yang dilakukan. Adanya berbagai peluang yang ada terkait promosi 
produk yang diantaranya adalh event pameran dan perkembangan teknologi informasi diharapkan dapat dimanfaatkan secara optimal untuk menunjang promosi produk. Oleh karena itu, keterbatasan dalam hal promosi dapat dikendalikan dengan penggunaan media - media promosi yang saat ini berkembang.

$\begin{array}{lr}\text { b) Pemanfaatan } & \text { fasilitas } \\ \text { pemerintah } & \text { untuk } \\ \text { meningkatkan } & \text { inovasi }\end{array}$
permodalan dan pemasaran.

Adanya perhatian pemerintah terhadap pemberdayaan usaha kecil menengah merupakan peluang yang dapat dimanfaatkan pengrajin dalam meningkatkan kualitas usaha mereka. Program pembinaan dan pelatihan yang dapat meningkatkan kualitas SDM pengrajin dalam manajemen usaha serta bantuan permodalan dalam bentuk subsidi bunga. Selain itu, adanya pameran yang dapat menunjang promosi produk sarung tenun. Beberapa fasilitas tersebut dapat dimanfaatkan pengrajin untuk meminimalkan permasalahan dalam hal inovasi produk, permodalan, dan promosi.

\section{Strategi $\mathbf{S}-\mathbf{T}$}

Strategi S - T (Strength Threat) atau strategi kekuatan ancaman merupakan strategi untuk mengoptimalkan kekuatan internal yang dimiliki dalam menghindari ancaman. Alternatif strategi S-T yang dapat dirumuskan adalah sebagai berikut:

a) Meningkatkan efisiensi produk dan margin dengan menggunakan saluran distribusi yang pendek.
17

Ancaman dalam usaha sarung tenun diantaranya adalah fluktuasi harga bahan baku serta sulitnya mencari bahan baku pada saat penjual benang sedang kehabisan stok benang sutera. Hal ini akan mempengaruhi harga sarung tenun Samarinda dan biaya produksinya. Untuk meminimalkan ancaman tersebut maka pengrajin berupaya menjaga efisiensi produk dan margin promosinya dengan menggunakan saluran distribusi pendek.

b) Menjaga kepercayaan konsumen dengan kualitas produk melalui manajemen produksi yang lebih baik.

Salah satu upaya yang dapat dilakukan pengrajin dalam menghadapi persaingan adalah dengan memanfaatkan kekuatan berupa kualitas sarung tenun yang dimiliki dan kontinyuitas produk serta dengan menerapkan manajemen produksi yang lebih baik diharapkan mampu menjaga loyalitas konsumen dalam menggunakan sarung tenun mereka. Oleh karena itu, pengrajin harus mampu mengelola usahanya secara baik sehingga menjamin kualitas dan kontinyuitas produksinya.

c) Menjaga dan melestarikan rasa cinta akan budaya sebagai warisan leluhur serta memperbanyak jenis dan corak sarung tenun agar tidak terancam punah.

Menjaga dan melestarikan rasa cinta akan budaya sebagai warisan leluhur, kebudayaan kita dapat hilang jika kita tidak 
menjaganya dengan benar, tapi kebudayaan kita juga akan terjaga dengan aman jika kita menjaganya dengan benar serta sebagai generasi penerus kita harus terus selalu brinovasi dan memperbanyak jenis dan corak sarung tenun agar tidak terancam punah.

\section{Strategi W-T}

Startegi W - T (Weakness-Threat) atau strategi kelemahan-ancaman merupakan strategi untuk meminimalkan kelemahan internal dan menghindari ancaman eksternal. Alternative strategi yang dapat dirumuskan adalah:

a) Meningkatkan promosi produk dengan melihat perkembangan pasar serta meningkatkan alokasi waktu dalam kegiatan usaha.

Kelemahan dalam usaha sarung tenun diantaranya adalah keterbatasan dalam promosi serta minimnya waktu yang dicurahkan pengrajin dalam menenun menyebabkan waktu pengerjaan semakin lama. Untuk meminimalkan kelemahan kelemahan tersebut pengrajin dapat melihat perkembangan pasar sehingga mampu melahirkan ide - ide kreatif dalam melakukan metode promosi yang efektif serta pengetahuan pengelolaan usaha yang baik.

b) Melakukan pencatatan data produksi dan penguatan dana mandiri

Salah satu kelemahan yang terdapat dalam usaha sarung tenun Samarinda adalah pengelolaan keuangan atau pembukuan usaha yang belum rapi. Hal ini akan berdampak pada kesulitan pengrajin dalam mengkalkulasikan keuangan dalam usahanya. Oleh karena itu, melalui pencatatan dalam pengelolaan keuangan akan membantu pengrajin dalam menentukan keputusan. Selain itu, pengrajin juga dapat mengetahui tingkat pendapatan dari usaha sarung tenun Samarinda sehingga mampu mengatur aliran keuangan.

\section{Daftar Pustaka}

Darsoprajitno, 2002. EKOLOGI PARIWISATA. Angkasa Bandung Kotler Philip, Keller Kevin Lane. 2009. Manajemen Pemasaran. Edisi ke 13. Erlangga. Ciracas Jakarta.

Yoeti Oka, 1996. Pengantar Ilmu Pariwisata. Angkasa Bandung. www. Wikipedia.org/wiki/promosi. 